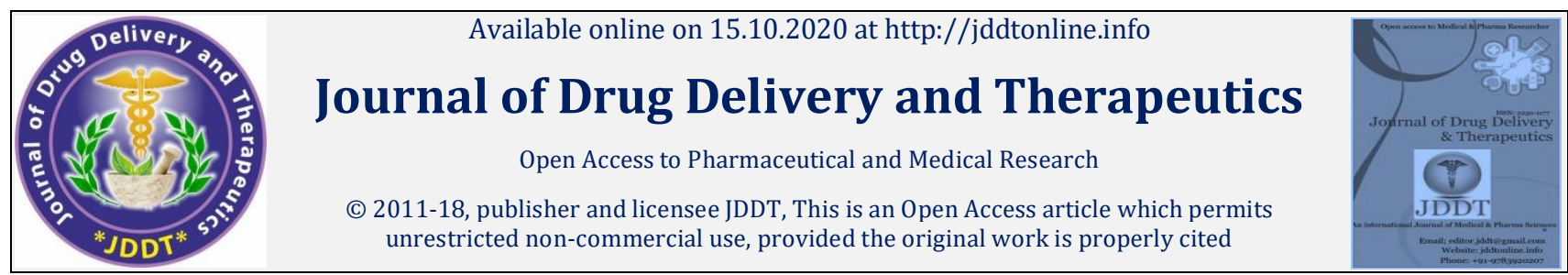

Open 1 Access

Research Article

\title{
Inhibitory Effect of Xanthine Oxidase from Tamus communis Roots Extracts/Fraction
}

\author{
ZERARGUI Fatima *, SAFFIDINE Karima, GUEMMAZ Thoraya, BAGHIANI Abderrahmane \\ Laboratory of Applied Biochemistry, Faculty of Nature and Life Sciences. Ferhat Abbas University Setif-1, 19000 Setif, Algeria
}

\begin{abstract}
In the course of our phytochemical studies of plant Tamus communis L., methanol soluble extract (EMeOH) (138 g) was chromatographed on a silica gel column. The column was eluted with chloroform and then with chloroform /methanol mixtures of increasing polarity. A total of 52 fractions ( $400 \mathrm{ml}$ each) were collected and grouped according to their TLC behaviour into 6 main fractions (I-VI). Total phenolic and flavonoid contents in these extracts were determined by a colorimetric method. Values varied between $73.143 \pm 0.009$ and $29.214 \pm 0.003$ equivalent Gallic acid/g lyophilisate. All the extracts showed inhibitory properties on xanthine oxidase, the $\mathrm{IC}_{50}$ ranges from $0.029 \pm 0.017 \mathrm{mg} / \mathrm{ml}$ to $0.237 \pm 0.026$ $\mathrm{mg} / \mathrm{ml}$. The extracts exhibited an additional superoxide scavenging capacity by using both enzymatic methods and $\mathrm{IC}_{50}$ values range from $0.039 \pm 0.023 \mathrm{mg} / \mathrm{ml}$ to $0.141 \pm 0.086 \mathrm{mg} / \mathrm{ml}$. These results show that Tamus communis $L$. extracts have strong anti-oxidant effects and may have some clinical benefits.
\end{abstract}

Keywords: Xanthine oxidase, Antioxidant, Superoxide scavenger, Tamus communis $L$.

Article Info: Received 18 Aug 2020; $\quad$ Review Completed 26 Sep 2020; $\quad$ Accepted 06 Oct 2020; Available online 15 Oct 2020

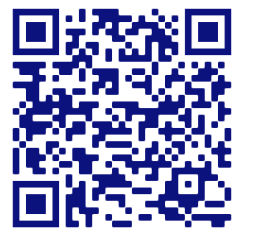

Cite this article as:

Zerargui F, Saffidine K, Guemmaz T, Baghiani A, Inhibitory Effect of Xanthine Oxidase from Tamus communis Roots Extracts/Fraction , Journal of Drug Delivery and Therapeutics. 2020; 10(5-s):164-169 http://dx.doi.org/10.22270/jddt.v10i5-s.4362

*Address for Correspondence:

ZERARGUI Fatima, Laboratory of Applied Biochemistry, Faculty of Nature and Life Sciences. Ferhat Abbas University Setif-1, 19000 Setif, Algeria

\section{INTRODUCTION}

Oxidative stress is defined in general as excess formation and/or incomplete removal of highly reactive molecules such as reactive oxygen species (ROS). In vivo, some of these ROS play a positive role such as energy production, phagocytosis, regulation of cell growth and intracellular signaling 1;2 however, excessive amounts can cause alteration in cellular reduction-oxidation (redox) balance, and disrupt normal biological functions. One of the very important enzyme that has been reported to increase during oxidative stress is xanthine oxidase (XO), which is conventionally seen as a late enzyme of purine catabolism, catalysing the oxidation of hypoxanthine to xanthine and of xanthine to uric acid 3 . Hyperuricemia leads to the accumulation of uric acid in joints and kidneys causing acute arthritis and uric acid nephrolithiasis. One therapeutic approach for gout is the use of XO inhibitors such as allopurinol 4. However, the use of allopurinol may cause a number of undesirable side effects 5 , ranging from mild skin allergy to a concerted allopurinol hypersensitivity syndrome 6;7. Thus, there is a need to develop compounds with XO inhibitory activities but devoid of the undesirable effects of allopurinol.
There is a growing interest in natural phenolic antioxidants, present in medicinal and dietary plants that might help attenuate oxidative damage ${ }^{8}$. Epidemiological studies have shown that many of these antioxidant compounds possess anti-inflammatory, antiatherosclerotic, antitumor, antimutagenic, anticarcinogenic, antibacterial, or antiviral activities to a greater or lesser extent 9;10, and it was found that their antioxidant activity surpasses the effect of known antioxidants, such as the vitamins $\mathrm{A}$ and $\mathrm{E}$ 11. Tamus communis L. plant is commonly used in folk medicine for various types of pathological cases. Previous studies have demonstrated certain antioxidant effects ${ }^{12}$. The purpose of this study was to investigate the antioxidant effect of root extracts of Tamus communis L. (TCE) and its active fractions using in vitro assays.

\section{MATERIALS AND METHODS}

\subsection{Materials}

Tamus communis was harvested from natural resources from Setif province in the northeast of Algeria, during the spring (May-June) mainly at flowering stage. Plant parts were dried for 7-10 days in shadow at room temperature then powdered and stocked in darkness until use. The 
authenticated was confirmed by Prof. Oudjhih University of Batna, Algeria. A specimen was deposited at the Laboratory of Botany, Faculty of natural and life sciences, University Ferhat Abbas Setif, Algeria. Bovine milk obtained from a local farm. All the other reagents were purchased from Sigma chemicals (Germany) and Fluka.

\subsection{Methods}

\subsubsection{Extraction}

Roots parts of the plant were cut into pieces, air dried and ground to a fine powder. The dried-powdered roots of the plant $(2 \mathrm{Kg}$ ) was extracted with $85 \%$ methanol $(10 \mathrm{~L})$ incubated for 5 days at room temperature. The extract was filtered through Whatman No. 41 filter paper to obtain particle free extract. The combined methanolic extracts were pooled, concentrated and dried under vacuum. Finally extracts were stored at $4^{\circ} \mathrm{C}$ and were used to explore their antioxidant activity.

\subsubsection{Fractionation}

The residual solid material (169 g) was extracted thoroughly with methanol. The methanol soluble fraction (138 g) was chromatographied on a silica gel column. The column was eluted with chloroform and then with chloroform /methanol mixtures of increasing polarity. A total of 52 fractions $(400$ $\mathrm{ml}$ each) were collected and grouped according to their TLC behavior into 6 main fractions (I-VI) (Fig.1).

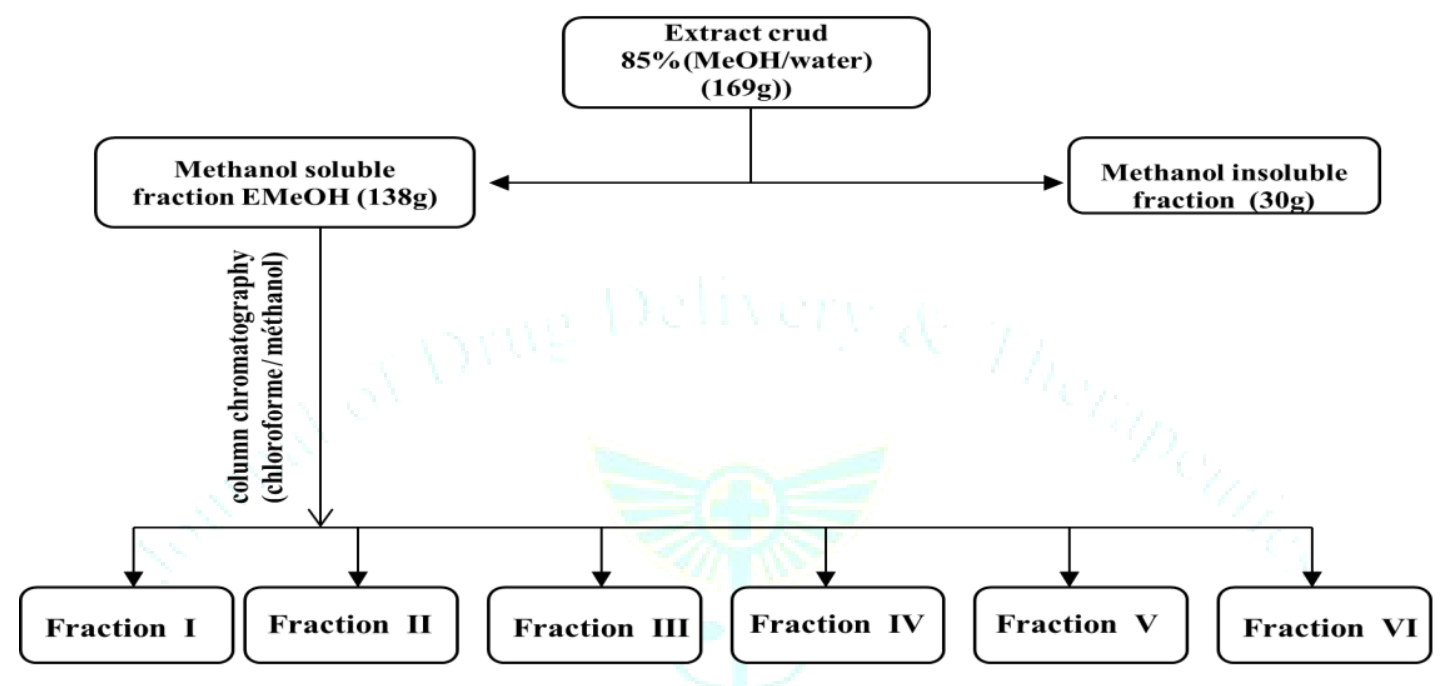

Figure 1: Different steps of extraction

\subsubsection{Determination of total phenolics}

Total phenolic content of Tamus communis.L extract was determined with the Folin-Ciocalteu's reagent (FCR) according to the published method 13 . Each sample $(0.5 \mathrm{ml})$ was mixed with $2.5 \mathrm{ml} \mathrm{FCR} \mathrm{(diluted} 1: 10, \mathrm{v} / \mathrm{v}$ ) followed by 2 $\mathrm{ml}$ of $\mathrm{Na}_{2} \mathrm{CO}_{3}(7.5 \%, \mathrm{v} / \mathrm{v})$ solution. The absorbance was then measured at $765 \mathrm{~nm}$ after incubation at $30^{\circ} \mathrm{C}$ for $90 \mathrm{~min}$. Results were expressed as Gallic acid equivalent (mg Gallic acid/g dried extract).

\subsubsection{Determination of flavonoid}

Flavonoids were quantified using aluminium chloride reagent $\mathrm{AlCl}_{3}{ }_{14}$. Flavonoids were measured as quercetin equivalents (Quer-Eq). $1 \mathrm{~mL}$ of $T$. communis samples are dissolved in methanol, then $1 \mathrm{ml}$ of $\mathrm{AlCl}_{3}(2 \%$ in $\mathrm{MeOH}$ ) was added, after incubation for $10 \mathrm{~min}$, the absorbance was measured at $430 \mathrm{~nm}$.

\subsubsection{Purification of milk xanthine oxidoreductase (XOR)}

XOR was routinely purified in our laboratory from mammalian milk (bovine), in the presence of $10 \mathrm{mM}$ of dithiothreitol, by ammonium sulphate fractionation, followed by affinity chromatography on heparin-agarose 15 . XOR concentration was determined from the UV-visible spectrum by using an absorption coefficient of $36000 \mathrm{M}^{-1} \mathrm{~cm}$ 1 at $450 \mathrm{~nm}$. The purity of enzyme was assessed on protein/flavin ratio (PFR $\left.=A_{280} / A_{450}\right)$ (Bray, 1975) and sodium dodecyl sulphate polyacrylamide gel electrophoresis
(SDS-PAGE) (10\%) 16. The XOR activity was determined by measuring the production of uric acid from xanthine (100 $\mu \mathrm{M}$, final concentration) at $295 \mathrm{~nm}$ using an absorption coefficient of $9600 \mathrm{M}^{-1} \mathrm{~cm}^{-1} 17$. Assays were performed at room temperature in air-saturated $50 \mathrm{mM}$ phosphate buffer, pH 7.4, supplemented with 0.1 mM EDTA.

\subsubsection{Effects of Tamus communis extracts on the generation of $\mathrm{O}_{2} \bullet$ radicals}

Anti-radical activity was determined according to Robak and Gryglewski 18 , by monitoring the effect of TCE on superoxide anion radicals $\left(\mathrm{O}_{2}{ }^{-}\right)$produced by xanthine/xanthine oxidase system. These radicals are able to reduce cytochrome c. The reaction mixture contained xanthine $(100 \mu \mathrm{M})$, horse heart cytochrome c $(25 \mu \mathrm{M})$, in air-saturated sodium phosphate buffer $(50 \mathrm{mM}, \mathrm{pH} 7.4)$, supplemented with $0.1 \mathrm{mM}$ EDTA and various concentrations of TCE. The reactions were started by addition of XO. Within $2 \mathrm{~min}$, reduced cytochrome c was determined at $550 \mathrm{~nm}$ against enzyme-free mixture using. The cytochrome c activity was calculated using an absorption coefficient of $21.100 \mathrm{M}^{-1} \mathrm{~cm}^{-1}$, and the sensibility of the reaction was determined by using bovine erythrocytes superoxide.

\subsubsection{Effects of Tamus communis extracts on Xanthin Oxidase activity}

The effect of TPE on the xanthine oxidation was examined at $295 \mathrm{~nm}$ following the production of uric acid using an absorption coefficient of $9600 \quad \mathrm{M}^{-1} \quad \mathrm{~cm}^{-1}$ by 
spectrophotometer 17. Assays were performed at room temperature, in presence of final concentration of $100 \mu \mathrm{M}$ of xanthine, in air saturated sodium phosphate buffer $(50 \mathrm{mM}$, $\mathrm{pH}$ 7.4), with various amounts of TCE dissolved in $\mathrm{MeOH}$. Control experiments revealed that solvent didn't influence the activity of $\mathrm{XO}$ at this concentration. The reaction was started by the addition of XO $(1176 \mathrm{nmol}$ of urate $/ \mathrm{min} / \mathrm{mg}$ protein) for Enzyme activity of the control sample was set to $100 \%$ activity. The percent inhibition was calculated by using the following formula.

$$
\text { The inhibition }(\%)=\frac{\text { Control OD - Sample OD }}{\text { Control OD }} \times 100
$$

\section{Statically analysis}

All determinations were conducted in triplicate or more and all results were calculated as mean \pm standard deviation (SD).

\section{RESULTS AND DISCUSSION}

\subsection{Determination of total polyphenol and flavonoids} contents

Total phenolic and flavonoids contents were expressed as mg gallic acid equivalents per gram dry weight (mg GA$\mathrm{Eq} / \mathrm{g}$ ) and $\mathrm{mg}$ quercetin and rutin equivalents per gram dry weight (mg Q-Eq/g) (Table 1) respectively.

There was a wide range of phenol concentration in different extracts. The highest level of polyphenols was recorded in FII followed by $\mathrm{EMeOH}$ (Table 1). Flavonoids were quantified using $\mathrm{AlCl}_{3}$ method described by Bahorun et al. 14 . Quercetin (Quer) and Rutin (Rut) are used as standards. Results showed that $\mathrm{EMeOH}$ gave the greatest level (Table 1). In this study, an attempt was made to quantify and identify polyphenols in Tamus communis.

Table 1: Total phenolic and flavonoid content in extracts/ fractions of $T$. communis

\begin{tabular}{|c|c|c|c|}
\hline \multirow[t]{2}{*}{ Extracts } & \multirow{2}{*}{$\begin{array}{l}\text { ttal phenolic content } \\
\text { tg GA-Eq/g extract) }\end{array}$} & \multicolumn{2}{|c|}{ Total flavonoid content } \\
\hline & & mg Q-Eq/g extract & mg R-Eq/g extract \\
\hline $\mathrm{CE}$ & $29.571 \pm 0.11^{\mathrm{a}}$ & $2.091 \pm 0.05 \mathrm{a}^{\prime}$ & $3.404 \pm 0.030 \mathrm{a}^{\prime \prime}$ \\
\hline MeOHE & $69.786 \pm 0.10 \mathrm{~b}$ & $8.080 \pm 0.07 \mathrm{c}$ & $19.387 \pm 0.11 \mathbf{b}^{\prime \prime}$ \\
\hline FI & $34.500 \pm 0.03 \mathrm{a}$ & $0.321 \pm 0.07 \mathbf{b}^{\prime}$ & $0.962 \pm 0.02 \mathrm{a}^{\prime \prime}$ \\
\hline FII & $73.143 \pm 0.09 \mathbf{b}$ & $0.755 \pm 0.04 \mathbf{b}^{\prime}$ & $2.092 \pm 0.007 \mathrm{a}^{\prime \prime}$ \\
\hline FIII & $37.500 \pm 0.06 \mathrm{a}$ & $0.621 \pm 0.04 \mathbf{b}^{\prime}$ & $1.479 \pm 0.03 \mathrm{a}^{\prime \prime}$ \\
\hline FIV & $30.5 \pm 0.06^{\mathrm{a}}$ & $0.141 \pm 0.09 \mathbf{b}^{\prime}$ & $0.487 \pm 0.07 \mathbf{c}^{\prime}$ \\
\hline $\mathrm{FV}$ & $32.071 \pm 0.03 \mathrm{a}$ & $0.394 \pm 0.07 \mathbf{b}^{\prime}$ & $1.070 \pm 0.26 \mathrm{a}^{\prime \prime}$ \\
\hline FVI & $29.214 \pm 0.03$ a & $0.359 \pm 0.02 \mathbf{b}^{\prime}$ & $0.954 \pm 0.06 \mathrm{a}^{\prime \prime}$ \\
\hline
\end{tabular}

Each value represents the mean \pm SD $(n=3)$. Total phenolic content was expressed as mg Gallic acid equivalent/g dried extract. Total flavonoid content was expressed as mg Quercetin and Rutin equivalent/g dried extract. Lines with different letters indicate activities significantly different $(\mathrm{p} \leq 0.05)$.

\section{2. Xanthine oxidase purification}

Isolation of $\mathrm{XO}$, as the widespread enzymes among different species, involves the extraction of the enzyme from a wide range of materials (bacteria, milk, organs of different animals, etc.) and its purification from crude extract. XO is concentrated in the milk fat/lipid globule membrane (MFGM), in which it is the second most abundant protein, after butyrophilin.
Freshly purified bovine milk XOR showed an ultraviolet / visible spectrum with three major peaks at 280, 325, 450 nm, with A280/A450 (protein to flavin ratio, PFR) of 5.078 indicating a high degree of purity ${ }^{19}$. Run on SDS-PAGE, purified enzyme showed quite similar patterns with one major band of approximately $150 \mathrm{KDa}$ (Fig. 2)
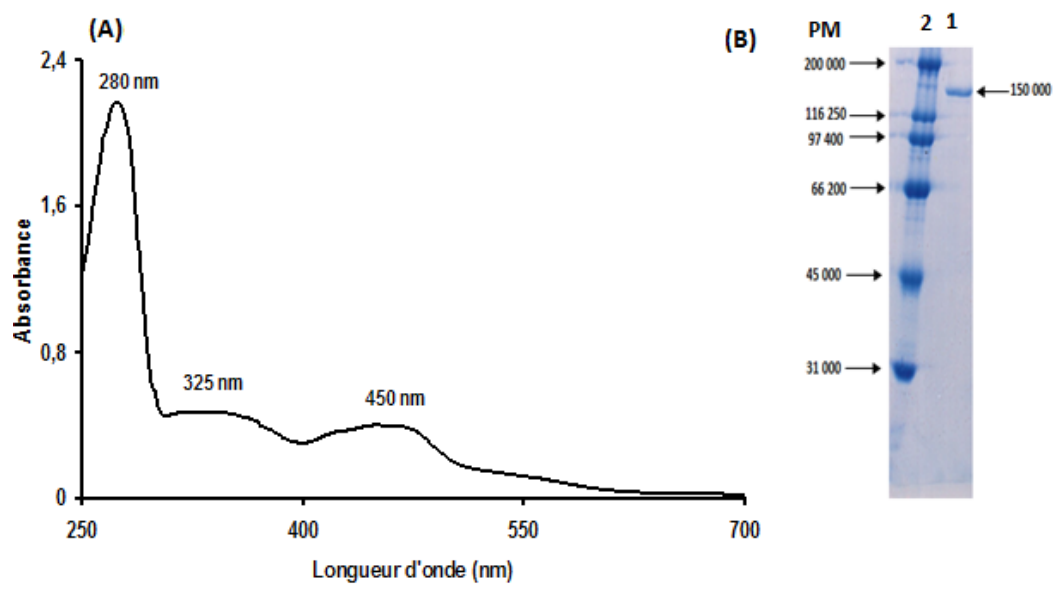

Figure 2: Spectre d'absorption UV-Vis (A) SDS-PAGE of XOR (B) B1: XO purified (150 000 Da), B2: markers (Myosin 200 000, $\beta$-galactosidase 116 250, Phosphorylase b 97 400, Serum albumin 66 200, Ovalbumin 45 000, Carbonic anhydrase 31000 Da). 


\section{3. Effects of TCE on the generation of $\mathrm{O}_{2} \cdot$ by the xanthine/xanthine oxidase system}

Cytochrome $\mathrm{c}^{3+}$ has been extensively used for the $\mathrm{O}_{2}$ detection produced in biological systems due to its fast superoxide-mediated reduction to cytochrome $\mathrm{c}^{2+} 20$. The effect of TCE at different concentrations were studied for their ability to scavenge $\mathrm{O}_{2}{ }^{*-}$ generated by the xanthine/xanthine oxidase system. The amount of $\mathrm{O}_{2}{ }^{-}$ generated was determined by measuring the reduction of cytochrome c. Under our experimental conditions, the activity of cytochrome $\mathrm{c}$ in the absence of extracts was ( $2135.91 \mathrm{nmols} / \mathrm{min} / \mathrm{mg}$ protein) reduced by $\mathrm{O}_{2} \cdot$ generated from XO. The reduction of cytochrome $\mathrm{c}^{3+}$ was almost totally inhibited by SOD $(330 \mathrm{U} / \mathrm{mL})$. Results showed that all the extracts were able to inhibit cytochrome $\mathrm{c}^{3+}$ (Fig. 3). The superoxide scavenging effect was found to increase with increasing concentration of TCE. The FV and $\mathrm{EMeOH}$ were the most potent scavenger of $\mathrm{O}_{2}$ - $\left(\mathrm{IC}_{50}\right.$ of $0,039 \pm 0,023$ $\mathrm{mg} / \mathrm{ml}$ ) followed by FIII $(0,040 \pm 0,023 \mathrm{mg} / \mathrm{ml}$ ) (Figure 1).

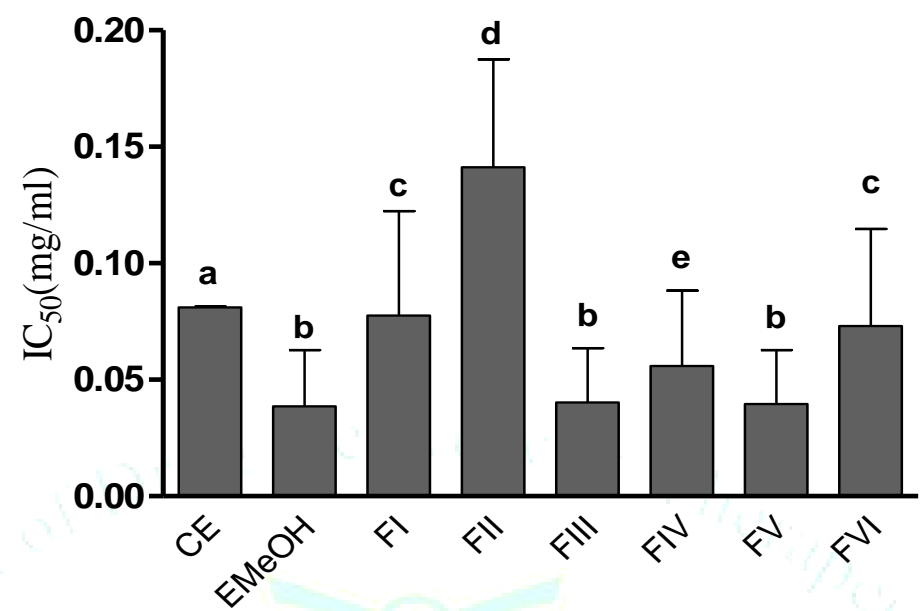

Figure 3: Comparison of inhibitory concentration of extracts/fractions of T.communis for $50 \%$ of Cyt C activity which reduced by $02 \cdot-$ generated from XO. Amount of superoxide anion radicals in the control sample without extract was set to $100 \%$. Each value is represented as mean \pm S.D $(n=3)$. Different letters indicate activities significantly different $(\mathrm{p} \leq 0.05)$

Xanthine oxidase activity, has been reported to increase during oxidative stress 21 , this enzyme is considered to be an important biological source of $\mathrm{O}_{2} \cdot$ which has been linked to post-ischemic tissue injury and odema $22 ; 21$.

\subsection{Effects of TCE on XO activity}

At the identical concentrations of TCE, we observed significant inhibition of $\mathrm{XO}$ activity in dose dependent manner. The inhibitory effects of TCE were compared with allopurinol, clinically used as a drug for the XO inhibitor (Fig. 4).

The results demonstrated that FIII possessed high XO inhibitory activity (IC $500.029 \pm 0.017 \mathrm{mg} / \mathrm{ml}$ ) followed by EMeOH and FII (0.030 $\pm 0.017 \mathrm{mg} / \mathrm{ml})$ (Fig. 4).

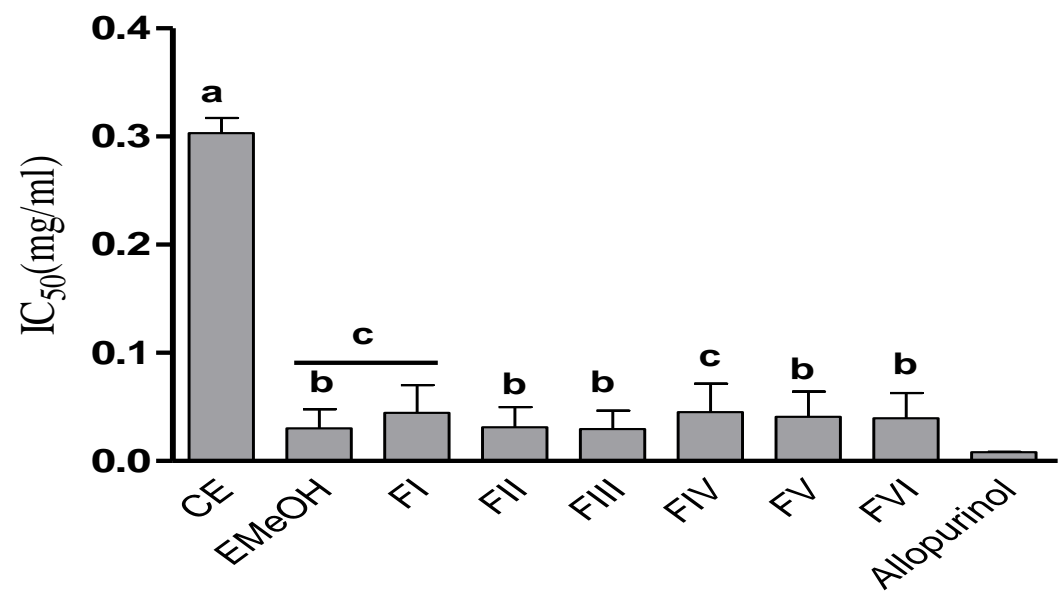

Figure 4. Inhibitory actions of extracts/fractions of T. communis on xanthine oxidase activity. Results are expressed as percentage of control where no inhibitor was added. Each value is represented as mean \pm S.D $(n=3)$. Different letters indicate activities significantly different $(\mathrm{p} \leq 0.05)$. 


\subsection{Evaluation of inhibition and scavenging effects of TCE}

The antioxidative properties of many compounds are brought by several different mechanisms, such as scavenging of free radicals, chelating of metal ions, such as iron and copper, and inhibition of enzymes responsible for free radical generation 23 . The half-maximal inhibitory concentrations of tested compounds for xanthine oxidase inhibition and reduction of the superoxide level are shown in (Fig. 5). Several data has been reported in many experimental models indicating that phenolic compounds are considered as antioxidants not only because they act as free radical scavengers, but also because of their ability to inhibit XO 24;25. This data showed that $\mathrm{IC}_{50}$ to scavenge superoxide radical of $\mathrm{CE}$ is low compared of the inhibition of the $\mathrm{IC}_{50}$ of $\mathrm{XO}$, this behaviour may be explicated by the fact that $\mathrm{CE}$ had a scavenging effect rather than an inhibitory action. The inhibition of Cyt $c$ reduction is due to the inhibitory effect of XO and / or to the scavenging effect on the $\mathrm{O}_{2} *$ produced by this enzyme ${ }^{26}$.

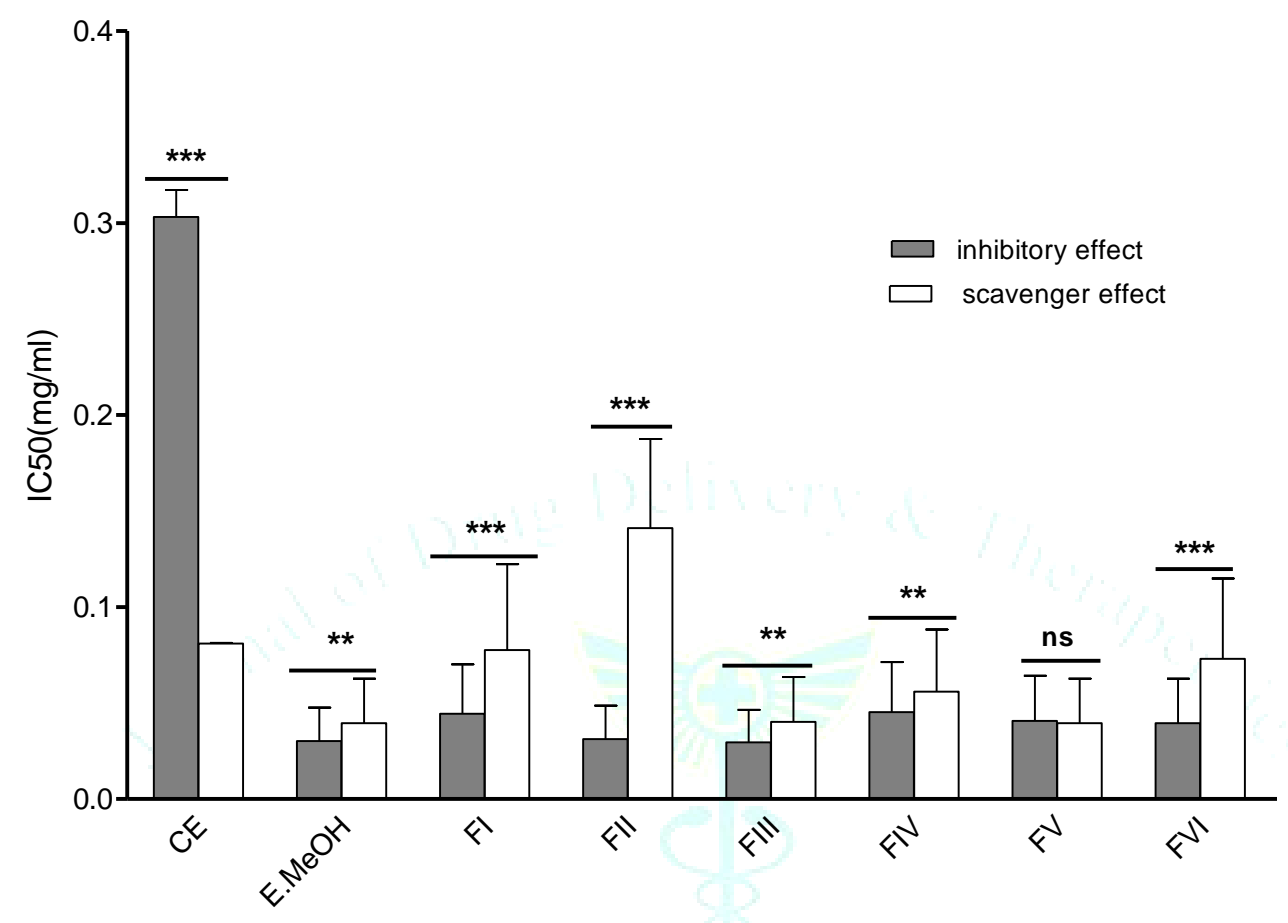

Figure 5. Evaluation of extracts/fractions as inhibitors of xanthine oxidase and as scavengers of superoxide produced by the action of XO enzyme. Each value is represented as mean \pm S.D $(\mathrm{n}=3) .{ }^{* * *} p<0.001,{ }^{* *} p<0.01$, ns : non-significant.

\section{CONCLUSION}

It has already been shown that the increase in xanthine oxidase activity is an important cause of the oxidative stress that occurs in the disease 27;28. Xanthine oxidase inhibitors (XOI) are typically used in the treatment of diseases related to hyperuricemia such as gout. Allopurinol is an allosteric xanthine oxidase inhibitor, which can decrease the damaging effect of xanthine oxidase in radical- mediated diseases, but the use of allopurinol is restricted by formation of oxypurinol, which is known to cause side effects ${ }^{29}$. Thus, a prompted search for new XO inhibitors that are structurally distinct from pureness is a necessity 30 . Hence, phytochemicals or extracts, which inhibit $\mathrm{XO}$ and the $\mathrm{O}_{2}{ }^{\circ}$ regeneration by the enzymatic pathway, would be beneficial in preventing these side effects. The potent capacity in inhibition of $\mathrm{XO}$ and $\mathrm{O}_{2} \cdot$ - scavenging activity exhibited by TCE and the different fractions can be explained by their phenolic compounds levels and/or the other type of phenolic compounds, to be discovered antioxidant compounds 31 . Enroth et al., 32 confirm existing structure-activity relationship. In phenolic compound, especially flavonoid, the hydroxyl groups at C-5 and C-7 and the double bond between C-2 and C-3 were essential for a high inhibitory activity on xanthine oxidase. Furthermore, they suggested that phe A planar flavone skeleton alone is insufficient to induce xanthine oxidase inhibition. It may be speculated that at least one hydroxyl group is necessary, favorable at position 7 , to achieve xanthine oxidase inhibition by flavones 32 .

The results clearly indicated that TCE are potent scavengers of $\mathrm{O}_{2}-$ This can prevent the formation of ROS, which can react with biological macromolecules leading to tissue damages 33 .

\section{ACKNOWLEDGMENTS}

This work was supported by the Algerian Ministry of Higher Education and Scientific Research (grant Nr 1220020) and by the Algerian Agency for the Development of Research in Health (ANDRS, grant $\mathrm{Nr}$ 02/12/02/04/045 \& $03 / 06 / 03 / 10 / 007)$. We express our gratitude to these organizations. The authors wish also to acknowledge the support offered by the University of Jordan which gave the first, fifth and sixth authors an opportunity to conduct this type of work using its facilities.

\section{REFERENCES}

1. Droge W. Free Radicals in the Physiological Control of Cell Function. PhysiolRev. 2002; 82(1):47-95.

2. Wenxin T, Lili T, Xiyan Y, Jiafu T, Fenglin D, Juan H, Kai G, Keith L, Xianlong Z, The calcium sensor GhCaM7 promotes cotton fiber elongation by modulating reactive oxygen species. 2014 . 
3. Harrison R. Physiological roles of xanthine oxidoreductase. Drug Metab Rev. 2004; 36:363-375.

4. Emmerson BT. The management of gout. N. Engl. J. Med. 1996; 334:445-451.

5. Wallach S L. The side effects of allopurinol. Hosp. Pract. 33: 22. (ROS) production. New phytol. 1998; 202(2):509-520.

6. Bouloc A, Reygagne P, Lecoz P, Dubertret L, Perforating foot ulceration with allopurinol therapy. Clin. Exp. Dermatol. 1996; 21:351-352.

7. Yale S.H, Yale ES, Mann DS. Fever, rash, and angioedema after a course of allopurinol. Hosp. Pract. 1996; 31:92-94.

8. Benzie IFF. Evolution of dietary antioxidants. Comp. Biochem. Physiol. 2003; 136:113-126.

9. Mclarty JW. 'Antioxidants and cancer: the epidemiologic evidence' in Antioxidants and Disease Prevention, H. S. Garewal, Ed., 45-66, CRC Press, New York, NY, USA. 1997.

10. Yang CS, Landau JM, Huang MT, Newmark HL. Inhibition of carcinogenesis by dietary polyphenolic compounds. Annu. Rev. Nutr. 2001; 21:381-406.

11. Demmig-Adams B, Adams WW. Antioxidants in photosynthesis and human nutrition. Science. 2002 298:2149-2153.

12. Zerargui F, Boumerfeg S, Charef N, Baghiani N, Djarmouni M, Khennouf S, Arrar L, Abu Zarga MH, Mubarak MS, Antioxidant Potentials and Xanthine Oxidase Inhibitory Effect of Two Furanocoumarins Isolated from Tamus communis L. Med. Chem. 2015; 11:506-513.

13. Wong SP, Leong LP, William Koh JH. Antioxidant activities of aqueous extracts of selected plants. Food Chem. 2006; 99:775783.

14. Bahorun T, Gressier B, Trotin F, Brunet C, Din T, Vasseur J, Gazin JC, Pinkas M, Luyckx M, Gazin M. Oxygen species scavenging activity of phenolic extract from howthorn fresh plant organs and pharmaceutical preparation. Arzneimittelforschung/Drug Res. 1996; 46(11):1086 - 1089.

15. Baghiani A, Harrison R, Benboubetra M. Purification and partial characterisation of camel milk xanthine oxidoreductase. Arch. Physiol. Biochem. 2003; 111:407-414.

16. Laemmli UK. Cleavage of structural proteins during the assembly of the head of bacteriophage T4. Nature. 1970; 227:680-685.

17. Avis P G, Bergel F, Bray RC, James DWF, Shooter KV. Cellular constituent, the chemistry of xanthine oxidase. Part II. The homogeneity of crystalline metalloflavoproteine fraction. J. Chem. Soc., 1956; 1212-1219.

18. Robak J, Gryglewski RJ. Flavonoids are scavengers of superoxide anions. Biochem. Pharmacol. 1988; 37:837-841.

19. Bray RC. Molybdenum iron-sulfer flavin hydroxylase and related enzymes. In: "The enzymes" 3ème Ed. PD Boyer Ed. Academic Press, New York. 1975; 12:299-419.

20. McCord, J. M. and Fridovich, I. The reduction of cytochrome C by milk xanthine Oxidase. J. Biol. Chem. 1968; 243:5753-5760
21. Matsumura F, Yamaguchi $Y$, Goto $\mathrm{M}$, Ichiguchi O, Akizuki $\mathrm{E}$, Matsuda T, Okabe K, Liang J, Ohshiro H, Iwamoto T, Yamada S, Mori K, Ogawa M. Xanthine oxidase inhibition attenuates kupffer cell production of neutrophil chemoattractant following ischemia- reperfusion in rat liver. Hepatology, 1998; 28:1578.

22. Hearse D J, Manning AS, Downey JM, Yellon D M. Xanthine oxidase: A critical mediator of myocardial injury during ischemia and reperfusion? Acta Physiol. Scand. 1986; 548:6578.

23. Benavente-Garcia O, Castillo J, Marin FR, Ortuno A, Del Rio JA Uses and properties of Citrus flavonoids. J. Agric. Food Chem. 1997; 45:4505-4515.

24. Cos P, Ying L, Calomme M, Hu JP, Cimanga K, Van Poel B, Pieters L, Vlietink AJ, Vanden Berghe D. structur - activity relationship and classification of Flavonoids as Inhibitors of Xanthine Oxidase and Superoxid scavengers. J. Nat. Prod. 1998; 61:71-76.

25. Boumerfeg S, Baghiani A, Messaoudi D, Khennouf S, Arrar L. Antioxidant Properties and Xanthine Oxidase Inhibitory Effects of Tamus communis L. Root Extracts. Phytother Res. 2009; 23:283-288.

26. Valentao P, Fernndes E, Canvalho E, Andrade PB, Seabra RM, Bastos ML Antioxidant activity of Hypericumandrosaeniuminfusion scavenging effect on superoxide radical, hydroxyl radical and hypochlorous acid Biol. Pharm. Bull. 2002; 25:1324-1327

27. Adkins WK, Taylor AE. Role of xanthine oxidase and neutrophils in ischemia-reperfusion injury in rabbit lung. J. Appl. Physiol. 1990; 69(6):2012-2018.

28. Romagnoli M, Gomez-Cabrera MC, Perrelli MG, Biasi $\mathrm{F}$, Pallardó FV, Sastre J, Poli G, Viña J. Xanthine oxidase-induced oxidative stress causes activation of NF- $\kappa \mathrm{B}$ and inflammation in the liver of type I diabetic rats. Free. Radic. Biol. Med. 2010; 49(2):171-177.

29. Hamanaka H, Mizutani H, Nouchi N, Shimizu Y, Shimizu M Allopurinol hypersensitivity syndrome: hypersensitivity to oxypurinol but not allopurinol. Clin. Exp. Dermatol.. 1998; 23:32-34.

30. Borges F, Fernandes E, Roleira F. Progress towards the discovery of xanthine oxidase inhibitors. Curr. Med. Chem. 2002; 9:195-217.

31. Abdullahi A, Hamzah RU, Jigam AA, Yahya A , Kabiru AY , Muhammad H, Sakpe S, Adefolalu FS, Isah MC, Kolo MZ Inhibitory activity of xanthine oxidase by fractions Crateva adansonii. J. Acute Dis. 2012; 126-129.

32. Enroth C, Eger BY, Okamoto K., NishinoT, Pai EF. Crystal structures of bovine milk xanthine dehydrogenase and xanthine oxidase: structure-based mechanism of conversion. Proc. Natl. Acad. Sci. 2000; 97:10723.

33. Aruoma $0 \mathrm{I}$,. Free radicals, oxidative stress, and antioxidants in human health and disease. J.Amer. Oil Chem. Soc. 1998; 75:199-212. 